Bol. Acad. peru. leng. 62. 2017 (267-320)

\title{
Mario Vargas Llosa: aproximación a la recepción de su escritura ensayística $(1972-2015)^{1}$
}

\section{Mario Vargas Llosa: Approach to the encounter of his essay writing}

(1972-2015)

\author{
Javier Morales Mena \\ Universidad Nacional Mayor de San Marcos
}

Resumen:

La producción intelectual de Mario Vargas Llosa (1936) no se restringe a un solo género literario. Si bien su faceta de novelista es una de las más estudiadas, también es autor de obras teatrales y ensayos literarios y políticos. Cuando se revisa la recepción que tienen sus textos, un considerable porcentaje de atención lo acapara su narrativa y, otro tanto, aunque en menor medida, lo tiene su obra teatral; en cambio, la recepción sobre sus textos ensayísticos literarios es muy escasa. Precisamente para contribuir con el conocimiento de

\footnotetext{
El presente artículo forma parte del primer capítulo de la tesis que preparé para optar el grado de Magíster en Literatura Peruana y Latinoamericana en la Unidad de Posgrado de la Facultad de Letras y Ciencias Humanas de la Universidad Nacional Mayor de San Marcos, esta tiene como título La representación de la literatura en la producción ensayística de Mario Vargas Llosa (2017).
} 
esta producción ensayística y la recepción de la misma, en este artículo presentamos tres de las tesis más difundidas al respecto: la del vacío epistemológico de Ángel Rama, la tesis de la autorreferencialidad de José Miguel Oviedo y la tesis de la homologación conceptual de Sara Castro-Klarén. Se trata de aproximaciones que comienzan en la década de los años setenta y llegan hasta fines de los años ochenta; y para complementar el horizonte de recepción hasta la actualidad, presentamos el replanteamiento de estas tesis en Ewa Kobylecka-Piwonska, Mabel Moraña, Belén Castañeda y Raymond L. Williams. Esta explicación del estado de la cuestión permite conocer cuáles son los problemas que se han configurado en estas décadas de recepción crítica sobre la producción intelectual vargasllosiana.

\section{Abstract:}

The intellectual production of Mario Vargas Llosa (1936) is not restricted to a single literary genre. While his role as novelist is one of the most studied, he is also author of plays and political and literary essays. When the reception of his texts is reviewed, a significant percentage of attention is captured in his narrative and ditto for, although to a lesser extent, his plays. In contrast, the reception on his literary essay texts is very scarce. It is precisely for that reason, to contribute to the knowledge of this essay production and reception of the same, this article presents the thesis of epistemological void of Angel Rama, the thesis of autoreferentiality of José Miguel Oviedo and the thesis of conceptual approval of Sara Castro-Klarén . These are approaches which start in the 1970s and continue until the end of 
the 1980s; and to complement the interval of reception until today, we present the review of these theses in Ewa Kobylecka-Piwonska, Mabel Moraña, Belen Castañeda and Raymond L. Williams. This explanation about the issue allows to know what the problems that have been set through these decades of critical reception on Vargas Llosa intellectual production.

Palabras clave: Mario Vargas Llosa, ensayos, crítica literaria, literatura.

Keywords: Mario Vargas Llosa, essays, literature critics, literature.

Recibido: 15/09/2017

Aceptado: 15/10/2017

\section{Primera tesis: el vacío epistemológico (1972)}

La producción ensayística literaria de Mario Vargas Llosa es, entre la totalidad de su obra, una de las menos estudiadas. Las reflexiones que se realizan sobre la misma se entremezclan y borran entre las páginas de la sección de reseñas de las revistas especializadas, las breves columnas de las publicaciones periódicas o entre capítulos de libros dedicados al análisis de su producción narrativa y teatral ${ }^{2}$. Uno de los primeros estudiosos que

2 Resulta ilustrativo mencionar la reciente publicación conjunta de Efraín Kristal y John King (eds.). The Cambridge to Mario Vargas Llosa (2015). En esta, King escribe el capítulo —no tan extenso- titulado: «The Essays» (148-173). Se trata de una presentación panorámica sobre Vargas Llosa ensayista político y literario. Sostiene el autor que la escritura vargasllosiana tiene una presencia sostenida por más de medio siglo, y no hay debate político, literario o artístico de relevancia donde no haya participado a través de sus artículos publicados en distintos medios: 
calibra el sentido que proponen estos ensayos fue el crítico uruguayo Ángel Rama (1926-1983), quien, en una serie de recensiones sobre el libro García Márquez: historia de un deicidio (1971), trazará un modo de lectura -lo explicaremos más adelante- que se replicará y extenderá por varias décadas. Los títulos de los artículos de Rama ${ }^{3}$, publicados originalmente en 1972 en el influyente semanario Marcha de Montevideo ${ }^{4}$, expresan el cuestionamiento del crítico literario frente

«indeed, his collections of essays often include open letters and documents that attest to his ongoing participation in public affairs in Peru and elsewhere» (148). [«de hecho, sus colecciones de ensayos, incluyen a menudo cartas abiertas y documentos que dan fe de su continua participación en los asuntos públicos tanto en el Perú como en otras partes del mundo» (en adelante, salvo se precise lo contrario, la traducción será nuestra)]; esta suerte de imagen de intelectual inmerso en los problemas de la sociedad ha hecho que - precisa King-Vargas Llosa sea catalogado como «the conscience of an era» (148) [«La consciencia de una época»].

3 Las reflexiones críticas que expuso Rama fueron replicadas por Vargas Llosa. La importancia de esta polémica y los argumentos de cada uno de los contendores hizo que se articularan en un libro cuyo título es García Márquez y la problemática de la novela (1973). En las páginas iniciales se lee que la controversia entre el crítico y el novelista: «dignificó en todo momento a ambos contendores no sólo por ratificar en él las notorias y brillantes dotes intelectuales sino porque, a partir de un chispazo de desacuerdo, se vieron obligados a discutir en el más alto nivel, uno de los temas esenciales de la literatura como quehacer humano: qué es la novela, qué es un novelista, cuál es la dinámica que lo sacude y lo mueve a ser» (5). Todas las referencias proceden de esta fuente.

4 Es incuestionable la significativa relevancia de Marcha (1939-1974), y de sus ediciones monográficas mensuales tituladas Cuadernos de Marcha (1967-1974), dentro del proceso de formación de la tradición crítica latinoamericana (Ruffinelli 1993: 30-37). Recordemos que desde temprano la consciencia crítica de Rama llamaba la atención sobre la importancia de sistematizar el campo de los estudios literarios latinoamericanos, labor que se debía realizar dejando atrás viejos enfoques historicistas; véanse al respecto dos artículos «La novela y la crítica en América» (1960) y «La generación hispanoamericana del medio siglo. Una generación creadora» (1964). Es en este último artículo donde Rama llama la atención sobre lo que falta por hacer en el campo de la crítica y la historiografía latinoamericana, por ello, sostiene: «mientras que el panorama crítico de las literaturas europeas evoca un jardín bien trazado y mejor cultivado, el americano recuerda una selva confusa donde los caminos se trazan dificultosamente, y muchas veces a machetazos» (1964: 2). 
a una serie de argumentos que expone Vargas Llosa en el texto dedicado al autor de Cien años de soledad (1967), leamos: «Demonio vade retro» $\mathrm{y}$ «El fin de los demonios». Evidentemente, se trata de títulos que de ninguna manera sugieren una positiva recepción del «ensayo» (24), por el contrario, tienen implícito el rechazo por considerarlo retrógrado (para el caso del primero) y próximo a clausurar su ciclo vital (en el caso del segundo); ambos títulos critican la idea vargasllosiana del novelista como un artista que escribe para exorcizar sus «demonios». Según Rama, estas reflexiones sobre el proceso de gestación de la novela - la llamada «teoría de los demonios» y el «deicidio»—, es negativa, «irracional» (28) y extremadamente individualista (86), pues pretende reinstaurar un tipo de concepción decimonónica sobre la creación literaria no acorde al momento histórico por el que atraviesa Latinoamérica: «reponerla hoy es perjudicar el esfuerzo de la cultura latinoamericana hacia más racionales niveles acordes con los proyectos de transformación de su sociedad» (25, nuestras cursivas); por lo mismo, la práctica crítica que realiza Vargas Llosa no solo se hace con un «método que corresponde a un siglo pasado» (28), sino también con un utillaje conceptual que bien podría ser ejemplo de «arcaísmo» toda vez que no se ajusta a «la metodología de nuestro tiempo» (27); el rosario de calificativos que acompaña a estas ideas complementa la valoración negativa que hace Rama de la práctica crítica vargasllosiana: «romántica» (8), de «origen decimonónico» (8) con una "concepción estética caduca» (9) y que se interesa más «por la génesis psíquica del arte que en la obra misma» (11). 
Los enunciados que acabamos de reproducir fragmentariamente no solo informan sobre la descalificación del quehacer crítico de Vargas Llosa, también connotan - uno a uno- la exigencia epistemológica de un campo disciplinario. Para Rama, el quehacer reflexivo vargasllosiano no alcanza rango de saber teórico, mucho menos crítico, no solo porque carece de alguna fundamentación epistemológica moderna, sino también porque las categorías conceptuales que emplea el novelista se adscriben a modelos explicativos provenientes del «historicismo» y el «biografismo» (24), los mismos que tienden a reducir el conocimiento del texto a cuestiones de «recuento biográfico» de la vida del autor en un matizado «marco histórico» (24); en tal sentido, lejos de los planteamientos de los «formalistas y estructuralistas» (78), también del "psicoanálisis postjunguiano, el neomarxismo occidental y la lingüística transformacional» (27), es evidente que la práctica crítica vargasllosiana no se toma como científicamente relevante o cognoscitivamente provechosa para el conocimiento de la literatura.

Para prevenir cualquier discrepancia con el modo de leer el ensayo de Vargas Llosa, Rama transcribe - estratégicamente- fragmentos de textos donde dos críticos literarios comparten sus apreciaciones con respecto al mismo objeto de estudio y en el mismo año. Uno de ellos es el mexicano Jorge Aguilar Mora (1946) y el otro, el peruano José Miguel Oviedo (1934). El crítico uruguayo transcribe del primero:

El libro de Vargas Llosa [García Márquez: historia de un deicidio] no solo me parece un gran fracaso, me parece también un libro muy peligroso [...] porque Vargas Llosa 
pretende justamente reunir los tres tipos de crítica sin el menor rigor, sin el mínimo compromiso intelectual; pero contribuyendo en cambio a la pobreza de la teoría literaria en Latinoamérica con términos anacrónicos, con definiciones retóricas absolutamente inútiles, con afirmaciones ambiguas que nunca dicen claramente todas las implicaciones que quieren producir [...] se aprovecha de nuestra pobreza crítica para proponernos ideas retrógradas, contradictorias, términos falsos, lugares comunes (citado en Rama 1973: 66, nuestras cursivas).

Menos extenso, del segundo se reproduce la reflexión a propósito de la teoría vargasllosiana del «deicidio»: «Además, ¿por qué únicamente escribir novelas es un acto deicida, una suplantación de Dios? ¿No podrán serlo también pintar cuadros, escribir poesía, componer música? La "teoría" puede abarcar tanto que ya empieza a contener poco» (citado en Rama 1973: 70). Las voces de estos dos lectores latinoamericanos, convocados por Rama, coinciden en señalar la debilidad conceptual de la crítica vargasllosiana. Como se lee, para el primero de ellos, el ensayo es "peligroso», «sin rigor», con «términos anacrónicos», "definiciones inútiles» e «ideas retrógradas», es decir, un ensayo que no contribuye al enriquecimiento de la teoría y la crítica latinoamericana (adviértase el énfasis en el sentido utilitario de la conceptualidad). Mientras que, para el segundo, el visible problema de la categoría clave «deicidio» tiene que ver con su excesiva amplitud, la cual estaría minando su pertinencia y precisión conceptual. Si lo advertimos, Oviedo tiene cuidado al reproducir la palabra teoría; él coloca el término entre comillas probablemente para sugerir que los argumentos vargasllosianos que se exponen no tienen el rigor ni la precisión 
epistemológica que debieran tener los enunciados propiamente teóricos (sin comillas).

Como se puede advertir, estas observaciones críticas realizadas desde coordenadas enunciativas y en estilos distintos, coinciden también con Rama toda vez que la debilidad conceptual del extenso estudio vargasllosiano no tendría un sólido y riguroso marco teórico. La puesta en evidencia de esta insuficiencia epistemológica estaría certificando que dentro de la "ciudad científica» (Coquet 2011: 122) latinoamericana los postulados vargasllosianos no pueden estandarizarse al análisis de la producción literaria de otros autores; así se estaría restringiendo la ciudadanía académica del novelista-crítico, es decir, se le reconoce la maestría y el rigor como novelista, pero su autoridad como teórico o como crítico estaría puesta en duda. Las coincidencias de estos enfoques críticos estarían destacando también que, a nivel latinoamericano, es unísona la preocupación por la hondura epistemológica de los estudios literarios, invocar y exponer sus exigencias fundamentales es como mantener a raya las aproximaciones críticas desarmadas e impresionistas.

Evidentemente que las máximas subtextuales que están funcionando como soporte de los argumentos de Rama pertenecen a algunos teóricos de la vanguardia rusa (Propp, Todorov) y otros del estructuralismo francés (Barthes, Bremond), pasando por la semiología (Greimas, Kristeva), la sociología literaria (Lukács, Goldmann) y la arqueología del saber (Foucault). No hay duda de que la invocación por el protocolo científico tiene una extensa tradición que comienza con los teóricos de la vanguardia rusa y que se actualiza, enriquece y culmina con 
el estructuralismo francés. Cuando Rama invoca estos nombres (contenedores de posturas teóricas y prácticas críticas distintas), lo hace para fundamentar y caracterizar la naturaleza del campo de los estudios literarios, un territorio donde la episteme, el método y el metalenguaje garantizan y sistematizan el conocimiento objetivo de la literatura. Compréndase que este imperativo epistémico no traduce en ningún momento la dictadura del inmanentismo. Rama cree en la productiva interacción entre el sistema social y el sistema literario. El ejercicio de la crítica, en tal sentido, debería ajustarse al modelo científico y a la crítica de las ideologías hegemónicas. Así es como lo escuchamos cuando reproduce el comentario del mexicano y del peruano.

La crítica de Rama al texto de Vargas Llosa se comprende, de este modo, como una afirmación de la necesidad de que los estudios sobre la literatura latinoamericana estén científicamente sustentados, si no por sus creadores, sí por sus críticos. En una de las entrevistas, justamente un año antes de la publicación de la discusión entre el uruguayo y el peruano, Rama decía:

La crítica literaria ha ido hacia una mayor brevedad, hacia una sustitución del juicio y del análisis por la información, a una sustitución de la interpretación por la mera descripción. Los periodistas han sustituido a los críticos: dado que lo que se pide es una información, la lectura de la solapa, algunos datos sobre la vida del escritor y alguna información para el gran público sabiendo «rascar» lo que él pide, eso lo puede hacer cualquiera, en la redacción de un periódico (1972: 12).

Evidentemente que la suya es una preocupación que se enmarca dentro de aquella demanda por crear las bases 
de un pensamiento y una práctica crítica moderna y rigurosa para explicar la literatura latinoamericana. Esta fue una preocupación que concernía tanto a críticos como a creadores, así se comprende el juicio de Octavio Paz (1914-1998), algunos años antes de la postura de Rama, escribe el poeta: «es un secreto a voces que la crítica es el punto flaco de la literatura hispanoamericana», pues "carecemos de un "cuerpo de doctrina" o doctrinas, es decir, de ese mundo de ideas, que al desplegarse, crea un espacio intelectual [para el desarrollo de la crítica]» (1967: 39, cursivas en el original); más adelante se redondea la constatación de esta carencia: «si se pasa de la crítica como creación a la crítica como alimento intelectual, la escasez se vuelve pobreza. El pensamiento de la época - las ideas, las teorías, las dudas, las hipótesis- está fuera y escrito en otras lenguas [...] si se pasa a la crítica literaria propiamente dicha, la pobreza se convierte en miseria» (1967: 40-41, nuestras cursivas). Referencias como las que acabamos de reproducir son numerosas, y todas señalan la necesidad de un pensamiento y una crítica modernos.

Si lo recordamos, el contexto de la discusión RamaVargas Llosa está en el tramo auroral del llamado «gran debate de los años 70» (Cornejo Polar 1999: 9), es en este contexto donde comenzarán a circular algunas publicaciones críticas que llamarán la atención sobre la necesidad de formalizar el discurso crítico latinoamericano, ya sea desde la afirmación de una posición ideológica o desde el entendimiento de sistematizar el aporte de las teorías literarias europeas; se puede mencionar, entre otros a: «Para una teoría de la literatura latinoamericana» (1972), de Roberto Fernández Retamar (1930) y el 
libro conjunto que coordina César Fernández Moreno (1919-1985): América Latina en su literatura (1972)5. Se trata de un escenario donde la discusión epistémica e ideológica buscaba construir y producir una teoría geopolíticamente latinoamericana, para explicar aquella literatura que una década antes había logrado la internacionalización a través de la narrativa de los autores del llamado boom. Recuérdese, por ejemplo, el prestigio internacional alcanzado por Vargas Llosa a raíz de la publicación de su trilogía de los años sesenta: La ciudad y los perros (1962), La casa verde (1965) y Conversación en La Catedral (1969). Era evidente el desafío que este proceso planteaba para la crítica: ¿cómo y con qué instrumentos analizar estas y otras narrativas?, era más urgente aún la creación de un discurso crítico riguroso y moderno, pues se había dado cuenta de aquella solo panorámicamente en el ensayo inaugural de Carlos Fuentes (19282012): La nueva novela hispanoamericana (1969):

Antes de este libro, prácticamente no existía un lenguaje crítico para hablar de la novela moderna latinoamericana. Fuentes fue el primero en darnos un nuevo lenguaje crítico para fines de los años sesenta y muy repetido por otros críticos durante la década de los setenta, cuando por fin nos llegó la teoría crítica del estructuralismo y postestructuralismo, junto con el trabajo de los pioneros críticos para fines de los sesenta -Rodríguez Monegal, Ángel Rama, Fernando Alegría, Julio Ortega, José Miguel Oviedo y otros (Williams 2001: 57, nuestras cursivas).

5 Este importante volumen contiene, entre otros, algunos significativos trabajos como: «El barroco y el neobarroco», del novelista y crítico cubano Severo Sarduy (1937-1993); «La nueva crítica», del poeta y crítico venezolano Guillermo de Sucre (1933); «Literatura y subdesarrollo», del brasileño Antonio Candido (1918-2017) y «Una discusión permanente», del estudioso de la literatura hispanoamericana, el peruano José Miguel Oviedo (1933). 
El lenguaje crítico que refiere Williams es precisamente el que busca definir y caracterizar el comentario de Rama. Es decir, propone diferenciar la crítica académica y la crítica de los propios creadores ${ }^{6}$. En el fraseo y explicación del crítico uruguayo, obviamente, la primera, propia del crítico, es objetiva, penetrante y reveladora, mientras que la segunda es subjetiva y propia del novelista. En tal sentido, el texto que comenta Rama, uno de los más sistemáticos y ambiciosos que Vargas Llosa escribió hasta entonces ${ }^{7}$, arroja una conclusión explícita: el derrotero de la teoría y la crítica debe ser el de la formalización científica, y no el subjetivismo romántico. Así, el gesto de Rama se puede leer como una metáfora de la división social del trabajo dentro de la ciudad letrada latinoamericana, pues, efectivamente, la polémica trata de diferenciar y delimitar el alcance $\mathrm{y}$ funciones cognoscitivas que tienen tanto el novelista como el crítico en un contexto donde la internacionalización de la literatura latinoamericana demandaba

6 Como se precisa de otro modo: «La crítica literaria latinoamericana tiene peculiaridades que no pueden ignorarse. La revolución que se produce en su seno en los años sesenta procede de un grupo de autores que no pertenecían a la academia ya que eran, a su vez, los escritores que estaban ocupando la escena literaria del momento: Borges, Cortázar, Vargas Llosa, Onetti, García Márquez... En lugar de reunirse en torno a departamentos universitarios lo hacían en torno a revistas, y frente al lenguaje hermético de la crítica académica su estilo era el de unos escritores que aspiraban a llegar a un público más amplio y transformar los hábitos de lectura. Pero esta situación va a cambiar en los años setenta» (Pulido 2009: 19, nuestras cursivas).

7 La primera experiencia escritural argumentativa de significativo aliento se desarrolla en uno de sus textos de tesis: Bases para una interpretación de Rubén Darío (1958), publicado en el 2001. Tanto este y el texto que reseña Rama cumplen el ritual académico para la obtención de grados universitarios; el primero para el grado de bachiller en la Universidad Nacional Mayor de San Marcos y el segundo para el grado de doctor en la Universidad Complutense de Madrid. Un detalle más, a manera de biografía intelectual: en términos de extensión, el texto sobre García Márquez será el más voluminoso, pues como él, no habrá otro en la producción ensayística del autor. 
como correlato la modernización de un discurso crítico ${ }^{8}$ que describa y explique rigurosa y formalmente la galaxia de sentidos (estructurales e ideológicos) que proponían las narrativas:

A pesar de que la vitalidad cultural parecía desmentir el balance de épocas anteriores, el estado de la crítica no presentaba el mismo vigor que la desbordante producción narrativa, y pronto empezará a ser notorio el desajuste entre una narrativa que se expande y renueva constantemente, y una crítica que trata de ponerse a la altura pero que no siempre encuentra los medios ni los argumentos. Es cierto que la crítica comparte en buena medida la euforia e interviene con sus mejores instrumentos teóricos, pero el voluntarismo de unos pocos no podía compensar las carencias del sistema en materia de instituciones críticas. El problema se hará más acuciante a principios de la década siguiente, cuando los críticos sean a menudo desplazados y sustituidos en la función analítica y divulgativa por los periodistas y por los propios escritores, en una postergación que fue especialmente hiriente para críticos concienzudos como Rama (Sánchez 2009: 91-92, nuestras cursivas).

Como se habrá advertido, tras la argumentación de Rama a propósito de qué es y no es científico y riguroso, existe una clara demarcación de las competencias $\mathrm{y}$ funciones de los sujetos que participan dentro del campo literario. Se trata de trazar fronteras y atribuir deberes y derechos a cada uno de los implicados en el quehacer literario; en sus propias palabras:

8 Para tener un conocimiento de los antecedentes reflexivos de la cuestión teórica y crítica sobre lo literario, véanse: El deslinde (1944), de Alfonso Reyes (1889-1959); el logrado intento crítico sobre el discurso poético que Octavio Paz propone en El arco y la lira (1956) y sus coincidencias y discrepancias con el estructuralismo en Claude Levi-Strauss o el nuevo festín de Esopo (1967); así también merece atención el ensayo teórico-crítico del cubano Severo Sarduy: Escrito sobre un cuerpo (1969) y su clásico ensayo mencionado en la nota 4. 
Carecemos de un debate metodológico entre los grandes críticos de Hispanoamérica. La crítica se mantiene dentro de un campo empírico y hasta pragmático. No cumple papel civilizador, que es la única función central del crítico, función de creación importante, porque es la suya propia. No es de ninguna manera hacer a la manera de un escritor o sustituir a un escritor, sino hacer un aporte creativo en el mundo de la interpretación y significado de los valores de una sociedad, para esta sociedad, dentro de la cual trabaja (Rama 1972: 15, nuestras cursivas).

Si articulamos estos y los otros argumentos que Rama expone sobre la escritura crítica vargasllosiana, se tiene claro que busca reorientar el derrotero de estos dos sujetos que participan en el campo literario: por un lado, los escritores, con su poética y sus inquietudes subjetivas sobre la creación, la lectura y la crítica; y, por otro lado, el crítico literario, con los modelos de análisis, su tropología y su teoría. El primero reflexiona sobre su quehacer narrativo, busca dar respuesta a una compleja red de interrogantes sobre cómo se escribe, por qué se escribe, para quién se escribe y qué sentido persiguen las historias de sus textos; el segundo observa la poiesis narrativa, se pregunta por las estructuras discursivas, la impronta ideológica y la inserción de la propuesta textual dentro del marco de una tradición regional o universal. Se trata de la demarcación disciplinaria de roles de observación (teórica) y participación (práctica) (Mignolo 1989: 42; también, Rancière 2009: 14-18).

La lectura crítica de Rama no deja elementos que podamos rescatar del libro vargasllosiano sobre el nobel colombiano. Este modo de insistir en la insuficiencia teórica define una de las tesis más difundidas y reproducidas sobre la ensayística literaria vargasllosiana: esta 
tiene un profundo vacío epistemológico que redunda tanto en un endeble marco teórico como en la falta de una terminología metalingüística apropiada. La tesis del vacío epistemológico es una postura argumentativa que considera que los enunciados críticos deben cumplir con los siguientes rasgos: la objetividad (que se traduciría en el empleo despersonalizado del lenguaje), el metalenguaje (que se calibraría por su precisión descriptiva que no genera ambigüedad) y el método (que se examinaría por la adscripción a un procedimiento que conduzca a la obtención de un conocimiento verdadero); y si en caso el enunciado o la formalización crítica adoleciera de estos componentes, o si alguno de ellos no fuera funcionalmente operativo, pues se trataría de enunciados críticos con un profundo vacío epistemológico.

Recordemos que la lectura de Rama está centrada en García Márquez: historia de un deicidio (1971). Podríamos pensar que sus opiniones respecto a Vargas Llosa crítico cambiarían con el transcurso del tiempo y la lectura de otros ensayos, pero nos equivocamos. En el prólogo a La guerra del fin del mundo $(1983)^{9}$, los encomios para el novelista, a quien califica como «nuestro mayor clásico vivo» (335), se acompañan de flashbacks sobre algunas escaramuzas conceptuales que sostuvieron precisamente en torno a la publicación del libro sobre el autor de Cien años de soledad (1967); recuerda el crítico uruguayo: «Una vez polemizamos Mario Vargas y yo a propósito

\footnotetext{
9 El texto en mención tiene como título: «La guerra del fin del mundo: una obra maestra del fanatismo artístico». Se trata del prólogo que Rama preparó para esta novela en la edición del Círculo de Lectores (1983); las referencias que realizamos proceden de Ángel Rama. La crítica de la cultura en América Latina (1985: 335-363).
} 
del género novela. Él estaba imbuido del subjetivismo astuto de sus primeras creaciones [...] (los dichosos fantasmas o demonios) que por los productos objetivos y sus efectos sobre el medio» (345, nuestras cursivas); pero aquellos elogios también corren junto con las ideas que remarcan el alcance conceptual de las reflexiones vargasllosianas a propósito de la literatura, sostiene Rama: «Su ensayo Albert Camus y la moral de los límites (1975) es una penetrante lectura del pensamiento de Camus y mucho más que eso: una autodefinición, el esfuerzo más sistemático hasta la fecha de Vargas Llosa para exponer sus propias ideas» (258-259, nuestras cursivas). A pocos años de la polémica sobre los demonios y el proceso de apropiación de la realidad, Rama reescribe esta variación sobre el mismo tema haciendo saber que las reflexiones vargasllosianas sobre el quehacer literario de otros autores, es decir, esta suerte de ejercicio crítico del novelista, sirven para ilustrar sus ideas sobre la literatura, y no para conocer profundamente la obra de los autores que aborda. El susurro de la tesis del vacío epistemológico se deja oír en cada palabra que destaca el talento narrativo de su otrora contendor.

La línea de lectura que realiza Rama, ¿será la única forma de aproximarse a la ensayística de Vargas Llosa? Cuando se lee la producción ensayística literaria vargasllosiana, ¿solo se calibrará si obedece o no al protocolo de escritura científico-literaria? ¿En lugar de comprender el sentido de las estructuras argumentativas, solo se analizará la profundidad sin fondo de los vacíos epistemológicos? Si bien no es la única forma de leer los ensayos de Vargas Llosa, sí es, en cambio, uno de los modos acríticamente más replicados y difundidos. 


\section{Segunda tesis: la autorrepresentación (1982)}

Casi una década después de la primera imagen que dejó la tesis de Rama sobre un profundo agujero negro: sin teoría, sin metodología y metalenguaje críticos, José Miguel Oviedo (1934) complementará la reflexión sobre la ensayística vargasllosiana en el texto Mario Vargas Llosa: la invención de una realidad (1982) ${ }^{10}$, ahí evalúa sucintamente lo que hasta entonces era el corpus ensayístico vargasllosiano: Gabriel García Márquez: historia de un deicidio (1971), La historia secreta de una novela (1971), El combate imaginario. Las cartas de batalla de Joanot Martorell (1972) y La orgía perpetua Flaubert y Madame Bovary (1975). Para Oviedo, estos textos hacen evidente el interés teórico y la vocación crítica que tiene el novelista, pues en ellos no solo se reflexiona sobre el proceso de concepción de la novela, sino también se analiza técnicamente cada uno de los elementos con los que están compuestas las ficciones de estos autores cuya producción literaria resulta fundamental tanto para la tradición literaria latinoamericana como para la española y la francesa. Si bien este interés teórico-crítico puede llevarnos a pensar que los argumentos vargasllosianos son universalizables — por ejemplo: la «teoría de los demonios»-, Oviedo advierte que:

Los «demonios» podrán ser útiles como instrumentos para la indagación de otros casos semejantes, el de García Márquez, por ejemplo, pero poco más: no puede elevarse, como querría Vargas Llosa, a categoría de explicación

10 Todas las referencias proceden de esta edición, salvo se precise lo contrario. 
universal del ejercicio novelístico: no todas las novelas se escriben por las mismas razones (346, cursivas en el original).

Es decir, en sentido estricto, los conceptos acuñados por el novelista, los argumentos que expone en cada uno de sus ensayos a propósito de la génesis y la composición de las novelas, no alcanzan rango teórico toda vez que no pueden ser universalizables; agrega Oviedo refiriéndose al extenso estudio sobre García Márquez: «Vargas Llosa ha construido su ensayo con una firme independencia frente a las teorías críticas en boga, les ha dado olímpicamente la espalda, lo que aumenta el carácter de testimonio personal de su crítica» (349, nuestras cursivas; no las perdamos de vista). ¿Cuáles son aquellas teorías que se han pasado por alto? ¿Por qué resulta importante destacar este hecho?

Evidentemente, el grueso de fundamentos teóricos que se ha dejado de lado se deduce de las corrientes y del autor que el propio Vargas Llosa menciona en la controversia con Rama: el formalismo ruso (21), las teorías lingüísticas del círculo de Praga (21) y Roland Barthes $(39,42)$. Ni más ni menos las orientaciones teóricas y el autor que le imprimieron más de un giro en trescientos sesenta grados al curso de la historia del pensamiento teórico literario, la primera de las escuelas con la creación de la llamada «ciencia literaria» (Eichenbaum 2008: 33), la segunda con la promoción y desarrollo del enfoque científico de la lingüística, en la línea del maestro ginebrino Ferdinand de Saussure (Trnka y otros 1971) y el tercero como ejemplo de quien lleva hasta sus límites el sistemático pensamiento estructuralista 
para percibir sus grietas y calibrar sus aporías - no en vano será quien ejemplifique en su práctica teórica: el paso de lo estructural a lo posestructural- (Pozuelo 1994: 142-148). En tal sentido, dejar de lado estas orientaciones teóricas - aquello que Oviedo precisa como darles «olímpicamente la espalda»—, no se comprende como una actitud gratuita sin más; en realidad, el gesto vargasllosiano está modelándose tempranamente como uno de resistencia al embate teórico (a este que exige, a cambio de la cientificidad y la objetividad, el precio elevado de amputar la sensibilidad y la subjetividad). Esta declarada resistencia temprana frente a la teoría será una constante en su quehacer reflexivo sobre el campo literario. Se trata de una resistencia que se niega a reconocer que, en cuestiones de interpretación y construcción de sentido, la autoridad del creador (novelista, poeta y dramaturgo), queda relegada o poco importa para el trabajo hermenéutico; tempranamente Vargas Llosa le dice ¡no! a este dictum barthesiano sobre «la muerte del autor» (Barthes 1968).

Antes del párrafo anterior colocamos en itálicas unas palabras que anticipan la respuesta a esta pregunta: ¿cómo catalogar, en tal sentido, la práctica crítica vargasllosiana? Oviedo tiene una serie de frases con las que se puede reconstruir la acepción del tipo de quehacer crítico vargasllosiano: «crítica de un novelista elaborado por un novelista crítico» (342), «crítica como autocrítica» (343), «laboratorio-espejo en el que él se observa creando» (343), «el método crítico es una confesión de parte del creador» (348), finalmente, como «testimonio personal» (349). El conjunto de estas acepciones traza los contornos del contenedor 
semántico de la práctica crítica vargasllosiana, esta es: subjetiva, personal e íntima. Una «crítica testimonial» cuyo estilo y sello personales se sustraen en su pretensión (epistemológica) y en su formulación conceptual (o metalingüística) del horizonte teórico o crítico del momento (sociocrítica, estructuralismo, posestructuralismo), no existe una adscripción al fundamento epistemológico de alguna de las teorías del siglo XX, mucho menos la adopción del utillaje conceptual de alguna de las orientaciones críticas de moda: "Vargas Llosa siente aversión por las pretensiones absolutistas y dogmáticas de un método» (350); en tal sentido, «el método crítico es una confesión de parte del creador, es un autorretrato racionalizado. El lector reconoce las huellas personales del Vargas Llosa novelista en cada paso que da el Vargas Llosa crítico» (349, nuestras cursivas).

Así las cosas, la imagen de la práctica crítica vargasllosiana no es otra cuando comenta el ensayo dedicado a la novela de Flaubert: Madame Bovary, publicado cuatro años después (1975). Ahí, Oviedo identifica la productividad hermenéutica que Vargas Llosa encuentra en el trinomio vida-obra-contexto; y pese a que no son de su interés los profundos cuestionamientos que se realizaron contra el biografismo o el historicismo, precisamente por ello, explica que el novelista-crítico: «remonta la corriente por fidelidad a sí mismo y sigue creyendo que la relación persona-sujeto creador es demasiado rica como para dejarla de lado, y se aprovecha de ella lo mejor que puede, para escándalo de muchos encandilados por las novedades [teóricas y metodológicas] del día» (350). 
Desconocemos si cuando el crítico peruano escribe "para escándalo de muchos», lo estaba haciendo refiriéndose a Rama, lo que sí resulta claro es que Oviedo no se «escandaliza» porque la crítica vargasllosiana no se adscriba a una corriente teórica de moda; de hecho, no pone demasiado énfasis en el problema del vacío epistemológico, ni en la explícita demarcación de roles y funciones tanto del crítico como del novelista; la lógica de sentido que propone su lectura no desautoriza las ideas vargasllosianas por carecer de fundamentos teóricos; lo que le importa, más bien, es precisar que esta práctica crítica tiende a prolongar las ideas que el mismo autor tiene sobre su poiesis narrativa, y que estaría haciéndose visible mediante la explicación de cada uno de los textos y autores analizados. De esta manera, la lectura de Oviedo da forma a otra de las tesis sobre la ensayística vargasllosiana: esta es autorreferencial. La tesis de la autorreferencialidad es una postura crítica, según la cual, en la lógica argumentativa de un texto A sobre B, en lugar de que $\mathrm{A}$ explique o analice lo que dice $\mathrm{B}, \mathrm{A}$ se constituye como objeto y como sujeto de sí mismo, y $B$ es un pretexto para prolongar el monologismo de A. Dicho de otro modo: los argumentos e ideas vargasllosianas sirven para comprender su poética novelística, más que el mundo representado de las obras de los autores analizados: «El lector reconoce las huellas personales del Vargas Llosa novelista en cada paso que da el Vargas Llosa crítico» (349).

Se habrá podido advertir que la tesis de la autorreferencialidad y la tesis del vacío epistemológico se complementan. Si no fuera porque su mirada crítica direcciona la puntería hacia el blanco sobre el vacío 
epistémico vargasllosiano, podríamos decir que Rama es quien hace derivar su tesis hacia la autorreferencialidad, y con ello sería también el promotor de esta postura de recepción; no obstante, hemos presentado a Oviedo como el alentador de esta tesis toda vez que su argumentación enfatiza este hecho, y no aquel otro. De todos modos, la explicación de ambas tesis, por separado, busca caracterizar cada una de estas posturas iniciales que, luego, con el discurrir del tiempo, podremos identificar (ampliadas y enriquecidas) en distintos y semejantes modos de leer la ensayística literaria vargasllosiana. Las que colocan el énfasis en el vacío epistemológico recurrirán a los argumentos expuestos por Rama, es más, como él, le reconocerán al novelista el talento y la genialidad creativa siempre en menoscabo de su actividad crítico-reflexiva. Las que extraigan alguna «utilidad» conceptual de las argumentaciones vargasllosianas, sobre todo para aplicarlas a los textos del propio novelista, invocarán directa o indirectamente la tesis de la autorreferencialidad propuesta por Oviedo. Existirá también un modo de lectura que movilizará ambas tesis a efectos de neutralizar cualquier alcance conceptual derivado de los ensayos del nobel, y para restringirlas solo al campo de la poética del autor.

\section{Tercera tesis: la homologación conceptual (1988)}

La presentación de las dos tesis que estamos realizando a propósito de la ensayística vargasllosiana, solo interroga los dos textos críticos más significativos, toda vez que ambos sintetizan intertextualmente buena parte de los argumentos críticos difundidos en revistas, 
diarios, capítulos de libro o monografías que orientan el sistema argumentativo hacia la tesis del vacío epistemológico o la autorreferencialidad. Dentro de esta lógica sinecdóquica, resulta significativo el texto de Sara Castro-Klarén (1942): Mario Vargas Llosa: análisis introductorio $(1988)^{11}$. Las ideas que expresa la autora sobre la novelística vargasllosiana se matizan con juicios críticos sobre algunos de sus ensayos: «Salazar Bondy y la vocación del escritor en el Perú» (1966) y «La literatura es fuego» (1967); así también, los libros sobre García Márquez, Madame Bovary y Entre Sartre y Camus (1981). Los fundamentos argumentativos de Castro-Klarén coinciden con los planteados por Rama y Oviedo. Cuando actualiza lo que el crítico uruguayo sostuvo hace más de una década, la estudiosa observa que los ensayos de Vargas Llosa no son un ejemplo de una «crítica sistemática» (84), menos, una «investigación exhaustiva» (84) toda vez que la suya es un ejemplo de «crítica preestructuralista» (85; léase: crítica precientífica, nuestras cursivas); y cuando sinteriza las ideas de Oviedo, precisa que la ensayística vargasllosiana sobre autores diversos, propone una reflexión "personal y vital» (84) para comprender al crítico más que la obra del autor estudiado.

Castro-Klarén no reitera lugares comunes a propósito de las formas de leer la ensayística vargasllosiana, pues además de actualizar la tesis de Rama y Oviedo, propone una forma provocativa (significativa e inaugural) de aproximarnos a estos. Aunque con tibieza, su lectura homologa los conceptos esbozados por Vargas

11 Todas las referencias proceden de esta edición, salvo se precise lo contrario. 
Llosa con los que tienen Flaubert, Sartre y otros (hasta ahí nada novedoso). Dentro de los contados autores nominados para homologar, una alusión llama poderosamente la atención, se trata del ¡teórico! ruso Mijaíl Bajtín. Las ideas de novela que tiene este se asemejan (en algo) con las del peruano:

No lejos de M. M. Bakhtin (The Dialogic Imagination, 1983), a quien Vargas Llosa parece no haber leído ya que no he encontrado referencias a la obra del teórico ruso, el novelista peruano considera que la novela es un género que «se alimenta de carroña», es decir, que «canibaliza» todas las experiencias y objetos accesibles al novelista [...] la coincidencia con Bakhtin, tiene, sin embargo, un fuerte e importantísimo matiz: el ruso habla de novela como discurso capaz de una voracidad infinita en cuanto incorpora a todos los otros discursos anteriores y posteriores a ella, mientras que Vargas Llosa habla del novelista -y por ende la novela- como el buitre que se alimenta de la carroña de la realidad o la experiencia (85, salvo el título del libro de Bajtín, las cursivas son nuestras).

Las palabras que acabamos de transcribir hacen evidente que la autora se conduce con cuidado. Sabe que su lectura es una provocación, sobre todo para los críticos que enarbolan la bandera de la hybris cientifista, aquellos a quienes Oviedo identificó como el grupo que se «escandalizaba» porque Vargas Llosa desoía - los cantos de sirena- del, para entonces, barroco concierto teórico. Acaso, por ello, escriba inmediatamente después de los nexos comparativos homológicos («no lejos de» y «la coincidencia»), la aclaración («importantísimo matiz») que sugiere proceder con cuidado a la hora de homologar argumentos. Aunque 
este último gesto pueda hacernos creer que se borra con la derecha lo que se escribió con la izquierda, no hay duda de que la suya propone una de las tesis provocativas que cierra la década de los años ochenta; una según la cual los argumentos vargasllosianos vertidos en sus ensayos pueden ser homologados con las ideas que, a propósito del mismo tema, propusieron - modernamente - algunos teóricos de la literatura. Esta tesis de la homologación conceptual es un postulado según el cual dos elementos que corresponden a esferas conceptuales distintas (el quehacer del escritor y el del crítico) se pueden equiparar o contrastar, toda vez que los componentes conceptuales de cada uno de ellos comparten entre sí aires de familia. Dentro del marco de ofertas interpretativas o protocolos de lectura que venimos comentando, es evidente que la tesis de la homologación conceptual de Castro-Klarén propone otro modo de leer e interactuar con la ensayística vargasllosiana.

El horizonte de recepción de la ensayística vargasllosiana hasta fines de la década de los años ochenta se expresa sinecdóquicamente en estas tres tesis cuyas propuestas son: leer la ensayística vargasllosiana sin reconocerle ninguna propiedad teórica o alcance crítico toda vez que sus constructos tienen un profundo vacío epistemológico y una escasa aplicabilidad crítica (la tesis del vacío epistemológico de Rama); comprender que la argumentación ensayística vargasllosiana proporciona insumos críticos para verterlas sobre sus propias ficciones (la tesis de la autorreferencialidad de Oviedo); y, finalmente, entender que, si bien las ideas de Vargas Llosa tienen una expresa resistencia a la 
teoría, a contrapelo de sus propias decisiones ${ }^{12}$, algunas de sus reflexiones sobre la novela (o el proceso creador) podrían leerse, por ejemplo, homologándolas con la argumentación de algunos teóricos de la novela contemporánea (la tesis de la homologación conceptual de Castro-Klarén). La fortuna que tuvieron estas tres tesis en el horizonte de recepción es diversa. Sin adelantar demasiado anotaríamos que desde fines de la década de los años ochenta hasta la actualidad, el horizonte de recepción sobre la ensayística vargasllosiana ha procedido, en los casos más radicales, suscribiendo al pie de la letra la tesis de Rama; y en los casos donde se ha buscado aprovechar las argumentaciones diseminadas en su ensayística, se ha optado por replicar la tesis de Oviedo; muy pocas lecturas se atrevieron a continuar la provocación de Castro-Klarén, acaso porque casi en su mayoría las aproximaciones que se realizan a la ensayística literaria confirman que la luz del logos y el acero de la razón instrumental no habitan en la práctica crítica vargasllosiana.

Para el vargasllosista Efraín Kristal (1959) existe un conjunto de hechos que cierta crítica literaria latinoamericana de la década de los años setenta (y se hace eco en los ochenta) no le perdona a Vargas Llosa: se trata del cuestionamiento que hace el novelista al socialismo cubano y a la figura que concentra el poder: Fidel Castro (1926-2016); se suma a ello la progresiva desafección por el socialismo y el «caso Padilla»; estos hechos calificados como contrarios al espíritu

12 En este punto es imposible no recordar su juicio a propósito de la deconstrucción, pues para Vargas Llosa, esta "[hace] de la crítica literaria una masturbación» (Vargas Llosa 2001: 32). 
revolucionario y al alma rebelde, habrían desencadenado una actitud de censura en la llamada crítica de izquierda (Mario Benedetti, Oscar Collazos, Carlos Rincón, Ángel Rama y algunos otros); se entiende por ello que la producción literaria y ensayística de Vargas Llosa haya sido juzgada más por animadversión política que por un juicio objetivamente crítico. Si antes de su «ruptura con el régimen» o su «desafección» con el orden cubano, los críticos le reconocían el talento y virtudes literarias, después de su carta de protesta dirigida a Fidel Castro y su renuncia al comité editorial de Casa de las Américas ${ }^{13}$, su obra recibió las peores críticas que llegaron, incluso, al «repudio [por sus] ideas literarias» (Kristal 2001: 348; Franco 2003: 135-136). No hay que realizar demasiado esfuerzo para advertir que el velo del juicio sociológico ha dejado ver el rostro del imperativo ideológico de la crítica literaria latinoamericana de aquella época:

Se deberían evitar las falacias que consisten, o bien en ignorar los méritos artísticos de una obra cuando el crítico discrepa de las posiciones políticas del autor, o bien en soslayar los defectos artísticos de la misma cuando el crítico concuerda con la ideología de este. El relativo éxito de estas prácticas tendenciosas en la crítica literaria latinoamericana ha sido lamentable: ha empobrecido la reflexión literaria haciendo pasar criterios politicos por artísticos y ha fomentado un acercamiento a la literatura que permite evaluar la misma obra como valiosa o despreciable en la medida que el autor que la produjo reconsidera sus opiniones políticas (Kristal 2001: 340, nuestras cursivas).

13 Véanse ambas epístolas en el conjunto de artículos reunidos bajo el título Contra viento y marea (1962-1982) (1983: 164-168). 
La reflexión que propone este estudioso de la obra de Vargas Llosa introduce una hipótesis de trabajo para explicar por qué la crítica literaria que otrora destacaba los méritos de la producción narrativa y la formación intelectual del novelista, luego de que este hizo públicas sus discrepancias con el régimen, esos mismos críticos escribían las peores invectivas sobre su persona y sobre su obra. No vamos a profundizar en esta explicación que es a todas luces acertada ${ }^{14}$. La traemos a colación para pensar, afinar el oído y responder si es que tras cada palabra que abre y cierra los reclamos de Rama a Vargas Llosa a propósito del método, el metalenguaje, la perspectiva científica, etc.; si es que detrás de esa cadena de imperativos disciplinarios, se deja oír el susurro de algunas voces que señalan que el fondo del asunto es la falta ideológica. No profundizaremos en estos detalles que nos conducirían por otros laberintos de la razón. Detengámonos aquí para retomar las interrogantes que orientaban nuestra reflexión: ¿puede ser posible que después de más de cuatro décadas desde la primera tesis sobre la ensayística literaria vargasllosiana, aún se continúe haciendo uso de sus principales fundamentos? ¿Es que cuando se trata de la lectura de la ensayística vargasllosiana la crítica literaria replica estas tesis pues opera acríticamente con ellas? ¿Cuándo se leen los ensayos de Vargas Llosa solo hay que hacerlos para encontrar alguna categoría fungible y útil?

14 El conciso recuento de Carlos Granés puede ser de utilidad para repasar los hechos que desencadenaron la ruptura entre Vargas Llosa y el régimen cubano: «[...] el enfrentamiento con Castro, sumado a la crítica que tres años antes había hecho a la invasión rusa a Checoslovaquia, generó el rechazo por parte de la izquierda latinoamericana» (2008: 55). 


\section{La proyección de las tres tesis sobre la ensayística vargasllosiana (1990-2013)}

Calibremos, a continuación, la presencia y ampliación de estas tres tesis en el horizonte de recepción del siglo XXI. Introduzcámonos, en tal sentido, en la lógica argumentativa de tres textos críticos donde es evidente la resonancia o la huella del imperativo epistemológico tanto como la presencia susurrada de la autorreferencialidad y la provocativa sugerencia de la homologación conceptual. Se trata de textos de diferente extensión. El primero es breve y está centrado en la ensayística y la reconstrucción de la poética del autor; el segundo es un extenso apartado donde se examina gran parte de la obra vargasllosiana en contrapunto con la obra de José María Arguedas; y el tercero es una sucinta presentación de sus ideas como ensayista en el marco de una reflexión mayor a propósito de su obra narrativa. Estas tres aproximaciones fueron publicadas en el siglo XXI. El primero de ellos por la hispanista polaca Ewa Kobylecka-Piwonska ${ }^{15}$ : «Teoría crítica de Mario Vargas Llosa: entre autorretrato y discurso autoritario» (2007); el segundo, por la prestigiosa intelectual uruguaya, Mabel Moraña (194?) Arguedas/Vargas Llosa. Dilemas y ensamblajes (2013); y,

15 Esta hispanista ha dedicado algunos artículos donde aborda la obra del novelista: «El lenguaje que expresa la realidad. Sobre el arte de la ficción de Mario Vargas Llosa» (2015), «El tiempo en la novelística de Mario Vargas Llosa» (2010), «Ser un novelista creativo. Teoría literaria de Mario Vargas Llosa» (2009), «La verdad de las mentiras: el realismo de Mario Vargas Llosa» (2009), «Teoría del tiempo narrativo de Mario Vargas Llosa» (2009), «Tiempo subjetivo en Travesuras de la niña mala de Mario Vargas Llosa» (2008), "Contra la naturaleza del lenguaje: el problema de la simultaneidad en la narrativa de Mario Vargas Llosa» (2007), «Mario Vargas Llosa: una realidad desdoblada o el procedimiento de los vasos comunicantes» (2006). 
el tercero, por el latinoamericanista norteamericano Raymond L. Williams (1950): Vargas Llosa: otra historia de un deicidio (2001). Si reparamos en los años de publicación de estos textos, podemos suponer que, a diferencia de Rama, Oviedo y Castro-Klarén, estos tienen un panorama bastante completo de la ensayística vargasllosiana, por lo menos, de los ensayos clásicos dedicados a los autores de la tradición literaria francesa: La orgía perpetua: Flaubert y Madame Bovary (1975), Entre Sartre y Camus (1981), La tentación de lo imposible. Victor Hugo y Los Miserables (2004); así también de algunos otros ensayos donde Vargas Llosa se ocupa de autores paradigmáticos para la narrativa latinoamericana contemporánea, además del Nobel colombiano: José María Arguedas o las ficciones del indigenismo (1997) y Viaje a la ficción. El mundo de Juan Carlos Onetti (2008); sin olvidar las recopilaciones de ensayos bajo títulos diversos, y que prestan atención a una variedad de temas como la espinosa cuestión política: Sables y utopías. Visiones de América Latina (2009), las mutaciones del orden artístico y cultural: La civilización del espectáculo (2012), los avatares de la fuerza social en el mundo contemporáneo: Desafíos a la libertad (1994), y las interpretaciones de las obras de autores como James Joyce, William Faulkner, Ernest Hemingway, Franz Kafka y Henry Miller, que se encuentran plasmados en los libros Contra viento y marea (1983) y La verdad de las mentiras. Ensayos sobre la novela moderna (1990). Con este panorama completo desde el mirador del siglo XXI, interroguemos, a continuación, cómo se actualizan y enriquecen las tres tesis que presentamos en páginas anteriores. 
El artículo de la hispanista polaca Ewa KobyleckaPiwonska: «Teoría crítica de Mario Vargas Llosa: entre autorretrato y discurso autoritario» $(2007)^{16}$, es bastante claro cuando sostiene que el novelista nunca tuvo una vocación teórica, pues sus escritos no pretendieron jamás la elaboración de una teoría literaria:

Vargas Llosa nunca se ha proyectado elaborar una teoría literaria de corte científico, y parece haber llegado a sus conceptos leyendo a otros escritores y haciendo caso omiso a los críticos, ya que en sus libros nunca hace alusión a las ideas clave de la moderna teoría de la literatura. Su pensamiento crítico constituye, pues, un dominio difícilmente susceptible de codificación, por ser más bien fruto de una aventura lectora que de una reflexión metódica (141, nuestras cursivas).

Desde que Rama escribiera alturada y beligerantemente la tesis del vacío epistemológico, hasta que, como leemos, la reescriba con algunas variaciones esta hispanista polaca, transcurrieron, por lo menos, tres décadas. El tiempo ha ido dejando atrás algunos imperativos regionales. En la transcripción que acabamos de hacer no hallamos el llamado por enrumbar las ideas para la forja de una empresa epistemológica latinoamericana, no encontramos, mucho menos, alguna invocación a los nombres de la tradición epistemológica europea (tampoco latinoamericana); acaso también porque el sujeto de enunciación no se interesa por calibrar las ideas vargasllosianas dentro del campo de las ofertas conceptuales de la ciudad letrada latinoamericana, en todo caso recordemos que a fines de la década del noventa

16 Todas las referencias proceden de Kwartalnik Neofilologiczny, LV, 2/2007. 
- poco antes de partir- Antonio Cornejo Polar había señalado que la pretensión de elaborar el proyecto de una teoría literaria latinoamericana, aquel imperativo movilizador de ideas que hallamos implícito en la argumentación de Rama, propias de las década de los años sesenta y setenta, había hecho visible numerosos defectos que la hacían imposible de sostener de cara al siglo XXI:

El proyecto de los 70 fracasó, y en efecto hoy no tenemos una teoría literaria hispanoamericana, tal vez -entre otras razones- porque epistemológicamente el reclamo quedó situado en un nivel muy abstracto (no crítica sino teoría) que entraba en paradójico conflicto con su propia urgencia de especificidad histórico-social. Me temo que, además, al menos en los momentos polémicos, se echó mano a las tesis más impactantes, pero menos certeras, de la teoría de la dependencia -y ya sabemos que ese callejón no tenía salida (Cornejo Polar 1999: 9, nuestras cursivas).

Para cuando escribe la hispanista polaca, es evidente que el proyecto latinoamericanista de construcción de una teoría literaria latinoamericana ha dejado de tener la resonancia epistémica que tenía en la década de los años setenta. En tal sentido, cuando la investigadora reescribe y actualiza la tesis del vacío epistemológico lo hace, específicamente, para constatar que la argumentación vargasllosiana sirve para evaluar su propia narrativa, más que para calibrar el universo de sentidos que proponen las obras que analiza; así, la falta de un marco teórico que oriente su práctica crítica expresa su vocación antimetódica «huérfano en materia de estudios críticos» (141); las ideas que se 
encuentran diseminadas por los ensayos vargasllosianos se tratarían, en tal sentido, de «reflexiones sobre el arte de novelar que lejos de ser una herramienta de análisis sistemático [...] goza de una perspectiva interior, casi intima, de un artista que intenta comprender [...] su discurso, en vez de ser neutral y puramente descriptivo, en algunos casos llega a volverse excluyente y dogmático» (141, nuestras cursivas).

Hemos destacado en itálicas algunas palabras, pues exigen distinguir lo subjetivo de lo objetivo; la locución adverbial que juega como fraseo correctivo «en vez de» exige el empleo del lenguaje objetivo, lo que podríamos denominar el imperativo de un metalenguaje, en lugar de aquel uso subjetivo e íntimo propio de una práctica crítica declaradamente subjetiva - y desarmada-; ¿se puede leer este requerimiento «en vez de» como el que actualiza la necesidad de comprender la división del trabajo literario en la ciudad letrada, es decir, el hecho de mantener a raya la distinción de roles y funciones de cada uno de los agentes: por un lado, el creador y, por otro, el crítico?

Otro escenario argumentativo donde oímos el susurro de la tesis del vacío epistemológico junto con la tesis de la autorreferencialidad, es en el texto de Mabel Moraña: Arguedas/Vargas Llosa. Dilemas y ensamblajes $(2013)^{17}$; así como lo hacíamos saber desde el inicio de este artículo, es una constante que las reflexiones sobre la ensayística literaria vargasllosiana se oculten y se entrelacen dentro de artículos, capítulos de libros, notas de periódicos o revistas donde se vierten juicios

17 Todas las referencias proceden de esta fuente, salvo se precise lo contrario. 
sobre su producción narrativa y teatral, es el caso del texto de Moraña. La lectura que realiza no está centrada en deslindar si es que lo que escribe el novelista es un ejemplo de crítica literaria o de ciencia de la literatura. Sus apreciaciones sobre la producción intelectual vargasllosiana están, más bien, entrelazadas, en general, con la imagen que tiene sobre su producción discursiva y, en particular, sobre su función como intelectual. Claro está teniendo como estructura de juicio y medida la comparación con la poética de José María Arguedas (1911-1969).

La estudiosa uruguaya no invoca explícitamente la tesis del vacío epistemológico, pero, en cambio, alude a una de sus figuras: «la falacia biográfica» (59), esta aparecerá estratégicamente no solo para desautorizar las ideas vargasllosianas sobre Arguedas, sino para precisar que se trata de un elemento constitutivo y repetitivo en sus ensayos en torno a otros novelistas. Esta falacia cuya nomenclatura evoca el biografismo decimonónico -y lo que ello significa para el pensamiento crítico moderno-, se hace acompañar, en diversos momentos de la argumentación, por categorizaciones que refieren el quehacer crítico como «anacronismo indefendible» (58), «trasnochado» y «psicologista» (207). Se trata de conceptos cuyos aires de familia aluden a lo precientífico. Es más, Moraña, en clara sintonía con los presupuestos de Rama y con los de Oviedo, aunque refiere más al primero que al segundo, explica cómo se debe comprender el ensayo vargasllosiano sobre el autor de Los ríos profundos (1958), según precisa: «más que echar luz sobre la estética o la ideología del biografiado, ayudan a caracterizar 
el modelo estético y representacional que el biografista construye para iluminar, por contraste con su objeto de estudio, los méritos de su propia factura literaria» (265, nuestras cursivas). Así, para la autora, los ensayos que Vargas Llosa escribe sobre los diversos novelistas, hacen evidente su voluntad de «controlar el campo intelectual; de marcar una dirección de recepción y de interpretación de obras que considera claves dentro de los registros internacionales» (136, nuestras cursivas); deducimos, por tanto, que cuando se deconstruyen sus pretensiones de autoridad crítica, haciendo visible —entre otros aspectos-, la «falacia biográfica» y la autorreferencialidad, se está reescribiendo la alegoría de la división social del trabajo literario dentro de la ciudad científica latinoamericana; parece decirnos Moraña que la de Vargas Llosa es una práctica crítica demasiado subjetiva y autorreferencial como para servir de insumo conceptual para construir argumentos sólidos dentro del campo literario: «su lectura de Arguedas constituye principalmente un ejercicio de desmitificación destinado a llamar la atención más sobre la persona del crítico —sus valores, posiciones y concepción de la literatura- que sobre aquel a quien secretamente considera su más elusivo y seguro contrincante» (136).

No hay un lugar donde se calibre de otro modo la reflexividad ensayística del nobel. Lo mismo da si es que el objeto de comentario es un ensayo o un libro dedicado a un autor en específico. La lectura crítica de Moraña proporciona una serie de calificativos que bien podríamos aislar solo para ilustrar el proceso de deslegitimación de la práctica crítica vargasllosiana 
«extrarracional» (206), lastrada de «lugares comunes» (206), con «superficiales abordajes» (206) y «argumentos improvisados» (212); por lo mismo, un quehacer intelectual signado no solo por la «verbosidad» (128), sino también por una especie de invasiva diseminación: «la escritura vargasllosiana prolifera en discursos, declaraciones, entrevistas, opiniones radiales o televisivas, columnas periodísticas, actuaciones teatrales, informes oficiales, etc., que revelan una necesidad de omnipresencia que tiende a saturar el espacio público» (127, nuestras cursivas).

Por momentos, la escritura de la uruguaya abre oscuros callejones donde se nos hace ver cómo, en nombre de Arguedas, se está ajustando cuentas con Vargas Llosa. Así las cosas, explica que transcurrieron «más de cinco décadas» (58) y Vargas Llosa no ha podido (¿ni pretendido?) construir otros argumentos (subjetivos) sobre la función de la literatura, el rol del novelista y el papel del intelectual; en sus escritos ensayísticos se advierte una «retórica plagada de lugares comunes» (58), una «máquina ruidosa que hace por momentos inaudible el sonido de la literatura» (39); se trata de una práctica crítica que, en detrimento del autor estudiado o biografiado, se «autopromociona» (262) con un claro «afán de figuración» (39, nuestras cursivas). Si reflexionamos sobre las palabras colocadas en itálicas, podemos deducir que además de la tesis del vacío epistemológico y de la autorreferencialidad, entraron en juego otros elementos propios de la espectacularidad ligada al mercado, la función del intelectual y su presencia en los medios, para la autora aquella propensión constante de «la búsqueda de 
universalidad que guía la labor intelectual de Vargas Llosa va dejando de ser la del humanismo [...] y apela cada vez más a la universalidad pragmática y degradada del mercado» (136, nuestras cursivas).

La lectura de Moraña no deja el recuerdo de alguna idea positiva que pueda aprovecharse de Vargas Llosa. Su lógica expositiva es como la de Rama, aunque moviliza mayores elementos toda vez que tiene un panorama completo de la ensayística vargasllosiana; puede destacar el talento narrativo del novelista, decir de su obra narrativa que es «altamente calificada» (217) y de su autor que es «poseedor de uno de los repertorios técnicos más nutridos y efectivos de la literatura contemporánea en lengua española» (217), y, puede también, a la vez, escribir que las reflexiones son sistemáticamente repetitivas y que la suya es una dicción de «charlatán». Leamos sus propias palabras:

La exploración de los límites de la literatura y de las fronteras del lenguaje ocupa buena parte de sus textos $\mathrm{y}$ de sus reflexiones [pero estas reflexiones se caracterizan porque son convertidas] en un tipo de ejercicio reproductivo, repetitivo y rutinario, dirigido a un receptor plural masificado [en estas] Vargas Llosa mismo se convierte en «hablador» en el sentido de charlatán, parlanchín, cuentero o lenguaraz, desplegando una locuacidad que compite con la elocuencia de su literatura (130, nuestras cursivas).

Moraña da cuenta de que las ideas de Vargas Llosa sobre las funciones de la literatura no se han modificado en poco más de medio siglo, esta iteración mina sus argumentos de «lugares comunes» y hace que sus explicaciones resulten «rutinarias», predecibles e imprecisas; la crítica que realiza la uruguaya, si bien 
no exige explícitamente el cumplimiento del protocolo de investigación científica (la objetividad y el metalenguaje), sí despliega argumentos sobre lo significativo de una práctica crítica instrumentada y teóricamente acorde con las exigencias socioculturales del texto (218). ¿Se advierte alguna actitud de desprecio a las masas cuando la autora identifica a los receptores de la producción discursiva vargasllosiana «receptor plural masificado»? ¿Existe algún error teórico o crítico en el hecho de aproximar las ideas teóricas al grupo de los grandes lectores? ¿O solo deberían comprenderlos los más entendidos?

La escritura de Moraña actualiza y sintetiza acertadamente tanto la tesis del vacío epistemológico (Rama), como la de la autorreferencialidad (Oviedo); introduce, asimismo, algunas otras variables como la tesis de la figuración y el mercado (en una clara sintonía con la tesis de Rama respecto a la relación del boom de la narrativa latinoamericana y el mercado). Desde que Rama formuló la tesis del vacío epistemológico hasta la actualización que Moraña hace de esta, por lo menos, pasaron cuatro décadas. ¿Por qué se continúa leyendo la ensayística de Vargas Llosa apelando directa o indirectamente a la tesis del vacío epistemológico y de la autorreferencialidad?, ¿por qué se continúa repitiendo acríticamente los mismos juicios y argumentaciones?, ¿es que no hay otra forma de aproximarse a esta producción crítica que no sea exigiéndole casi automática y mecánicamente el cumplimiento del protocolo científico? ¿Y qué fue de aquella otra tesis que provocativamente propuso Castro-Klarén sobre la homologación conceptual? 
Antes de explicar el valiente atrevimiento de Raymond L. Williams, en la continuación de la provocativa tesis de Castro-Klarén, resulta necesario explicar una significativa resonancia de la tesis de la homologación conceptual, pues esta se deja oír tras la exposición de la investigadora cubana afincada en los Estados Unidos, Belén Castañeda (194?); en la nota titulada: «Mario Vargas Llosa: el novelista como crítico» $(1990)^{18}$, esta parece sostener que existe un error metodológico en las aproximaciones que los críticos realizaron a la práctica crítica vargasllosiana (piensa en Rama, Oviedo y otros), pues estos en una especie de implícita confirmación de la tesis barthesiana respecto a que «el autor ha muerto», $y$, por tanto, sus opiniones sobre su obra importan poco, le han exigido al novelista la profundidad y el alcance epistemológico cuando este nunca se trazó ese objetivo, es más él mismo había prevenido de que «nunca ha pretendido crear una crítica literaria universal» (348); en este punto coincide con lo que décadas más adelante expresará el estudioso y traductor Jhon King (2015), para quien Vargas Llosa siempre afirmó no ser un "crítico académico» ni pretender modelar un tipo de crítica de ese calibre: «he has always assert that he is not an 'academic' critic» (149); por ello, Castañeda propone un trabajo crítico que debería comenzar por desautomatizar la percepción que condiciona las aproximaciones críticas que se hacen mecánicamente, por casi dos décadas (recuérdese que esta autora escribe a comienzos de la década de los años noventa):

18 Todas las referencias, salvo se precise lo contrario, proceden de «Mario Vargas Llosa: el novelista como crítico». Hispanic Review. Vol. 58. 
Para mejor poder evaluar la ideología y el acercamiento crítico de Vargas Llosa, y a la vez determinar la importancia de su obra crítica dentro de su obra total, es necesario examinar sus puntos de contacto con otras tendencias críticas, tanto como los elementos que separan y distinguen la aproximación teórica de Vargas Llosa de las practicadas hoy día. Propongo hacer esto a la luz de la crítica moderna, ya que Vargas Llosa la rechaza tan abiertamente por fijarse exclusivamente en los aspectos formales de la obra literaria y no en su totalidad (349, nuestras cursivas).

Se desprende del fragmento que acabo de transcribir - sobre todo de las palabras puestas en itálicas- que el trabajo crítico que realizará la autora deberá comparar y explicar la postura crítica vargasllosiana que, es cierto, "se aparta de la crítica basada en el modelo lingüístico, como la deconstrucción, el estructuralismo y la semiótica tanto como de la que estudia el contexto sociológico» (348), pero no por ello deberá proceder de manera automatizada, es decir, descartándose, desde un principio, cualquier aporte; para la autora la cuestión es mucho más estratégica, pues se tendrá que buscar espacios donde las ideas y los argumentos vargasllosianos coincidan con la crítica existente. Así, se explica que el énfasis vargasllosiano puesto en la cuestión biográfica en los estudios sobre la obra de García Márquez y Flaubert, si bien adscribe la crítica dentro de una orientación marginal como es el biografismo, esta tiene una intención crítica poco advertida. Se trata del sentido que busca conseguir Vargas Llosa con su insistencia por develar, para el lector, la génesis y el funcionamiento de los mecanismos de la relojería creativa del novelista, según la investigadora: «Vargas Llosa 
examina detalladamente los recursos literarios de tales escritores como García Márquez, Flaubert y Martorell para ver cómo han hecho al lector creer en sus "realidades ficticias" y absorberse en ellas» (355).

Castañeda lee en esta insistencia una aproximación a las modernas teorías de la lectura y la recepción, toda vez que las precisiones biográficas sobre cada autor o la descripción de los universos ficcionales en clave terminológica especialmente creada por Vargas Llosa («los vasos comunicantes», «la caja china» y «el salto cualitativo o la muda temporal»), completamente opuestos al «vocabulario lingüístico que se utiliza en la crítica de hoy día» (347), no se hacen con la intención de construir una teoría del sentido, sino pensando en explicarle a los lectores cómo se forjaron los elementos narrativos que el novelista hace confluir para modelar un mundo ficcional que capture al lector y que le haga experimentar diversas sensaciones:

La concepción literaria de Vargas Llosa es, por lo tanto, una ampliación y a la vez una transformación de distintas teorías del lector y del proceso de la lectura. Mediante la creación de «realidades ficticias», Vargas Llosa quiere impedir en el lector «la recesión espiritual, la autosatisfacción, el inmovilismo, la parálisis, el reblandecimiento intelectual o moral». Según explica en «Una insurrección permanente», la misión de la literatura es, por lo tanto, «agitar, inquietar, alarmar, mantener a los hombres en una constante insatisfacción de sí mismos; su función es estimular sin tregua la voluntad de cambio y de mejora aun cuando para ello deba emplear las armas más hirientes» (355).

Este pasaje escrito por la investigadora cubana, a escasos dos años de la tesis de la homologación conceptual 
propuesta por Castro-Klarén, si bien no hace alusión a la postura de esta, implícitamente explica la fuerza que mueve la comparación y el establecimiento de aires de familia entre la postura crítica vargasllosiana y las teorías de la lectura o teorías de la recepción. ¿Puede ello ser posible? ¿Y la hybris cientifista? ¿Y el vacío epistemológico? ¿Y la autorreferencialidad? Belén Castañeda reconoce la tesis de Rama y Oviedo. También comparte sus juicios e ideas respecto al alcance teórico o crítico de los argumentos vargasllosianos; en cambio, a diferencia de ellos - e incluso contrariamente de cómo pretendería Vargas Llosa que se leyeran sus ensayosdecide leer y encontrar puntos de contacto entre las ideas vargasllosianas sobre la novela con aquellas aproximaciones propiamente teóricas como la estética de la recepción o la teoría de la lectura. La suya es una nota crítica no extensa. Probablemente esa brevedad justifique la ausencia de un mayor desarrollo explicativo de la conjunción entre la postura crítica vargasllosiana y la estética de la recepción, pero dentro del panorama que venimos presentando, no hay duda de que se trata de una lectura que reorienta en trescientos sesenta grados la mirada que se tiene sobre la producción ensayística vargasllosiana. ¿Es una lectura a comienzos de la década de los años noventa, tendrá ampliación y ejecución?

Quien completa esta radical vuelta de tuerca respecto a la tesis de la homologación conceptual es el norteamericano Raymond L. Williams en su libro Vargas Llosa: otra historia de un deicidio $(2001)^{19}$. Como

19 Todas las referencias proceden de dicha fuente, salvo se precise lo contrario. 
lo anotáramos líneas arriba, se trata de un texto orientado a realizar un balance general sobre la producción literaria vargasllosiana, evidentemente, como el título lo indica, haciendo uso de una serie de insumos discursivos que provienen de la archivística biográfica, de la enciclopedia crítica o del libro de la historia universal y la historia social hispanoamericana. Ello quiere decir que la reflexión sobre la ensayística solo es parte de una totalidad mayor. Y como tal, evidentemente, los argumentos que se vierten sobre ella son fragmentarios. Pese a ello, las ideas que propone resultan novedosas toda vez que rompen con el automatismo de buena parte de la crítica que exigía a la escritura crítica vargasllosiana el irrestricto respeto del protocolo científico para escribir crítica literaria.

A diferencia de aquellos integrantes de la ciudad científica latinoamericana, Williams no desautoriza la escritura crítica vargasllosiana, pues no se aproxima a ella con algún imperativo epistemológico (y no porque lo desconozca); es cierto que escribe «poco "académico"» (90) refiriéndose a la crítica vargasllosiana, pero adviértase que coloca entre comillas el término académico, pues quiere dejar claramente establecido lo que él piensa y lo que piensan los demás; estas comillas que separan lo propio de lo ajeno proponen ensanchar la mirada crítica y calibrar los elementos que moviliza dicha escritura. Esta caracterización no pretende - como en Rama - reconstruir la genealogía decimonónica de las categorías para, luego, hacer visible su anacronismo y miseria conceptual, la suya es una descripción que destaca el hecho de estar frente a una escritura ensayística que tiene la particularidad de ser «altamente metafórica 
y cargada de múltiples significados y resonancias» (90), es decir, un tipo de «discurso crítico» que no solo es un «trabajo académico» o un «exhaustivo estudio crítico», sino además tiene el añadido de parecer también una «obra narrativa» (90). He transcrito entrecortadamente este enunciado toda vez que pretendo visibilizar de frase a frase la caracterización del lenguaje de la prosa vargasllosiana: esta es simbólica, intertextual, rigurosa y artística. Reescribamos, esta vez, de modo continuo, las ideas de Williams refiriéndose al extenso ensayo dedicado a García Márquez:

Este lenguaje crítico, al ser metafórico, es sumamente eficaz para un largo ensayo en el cual otro lenguaje más académico sería menos accesible. En cuanto al contenido, no presenta del todo una novedad. El concepto de los «demonios personales» es netamente freudiano, tal como son algunas otras ideas básicas de la estética vargasllosiana. El autor peruano también coincide con planteamientos anteriores de Nietzsche y Deleuze (91, nuestras cursivas).

La última imagen que tenemos registrada de la homologación conceptual nos recuerda que el atrevimiento de Castro-Klarén proponía calibrar (con cuidado) los puntos de contacto entre las ideas de novela de Vargas Llosa y Mijaíl Bajtín. Era la década de los años ochenta y en el horizonte latinoamericano la propuesta de la autora no tuvo mayor desarrollo, pues la reproducción acrítica de la tesis del vacío epistemológico y de la autorreferencialidad predominaban por sobre cualquier otro enfoque. El fragmento que acabamos de transcribir, propio de los primeros años del siglo XXI, plasma aquella tesis susurrada, pues — sin temor ni 
temblor - sugiere todo un estratégico programa de trabajo para abordar la ensayística vargasllosiana. Este quehacer crítico comenzaría por calibrar la simbología tropológica del lenguaje, también indagaría por aquellas visibles e invisibles huellas intertextuales que componen el tejido discursivo ensayístico, $y$, finalmente, se procedería a comparar, analogar u homologar las ideas vargasllosianas con algunas otras de autores propiamente teóricos o críticos. Si lo advertimos, se trata de un modo radicalmente distinto de interactuar con el texto ensayístico o con el discurso crítico vargasllosiano. No se desestima - desde un inicio- su comprensión; no se le coloca en condición de marginalidad epistemológica; $\mathrm{y}$, mucho menos, se remarca su anacronismo. Así, la puesta a prueba de este nuevo acercamiento haría percibir, por ejemplo, que en «la teoría de los demonios» se dejan oír resonancias explicativas de las fuerzas traumáticas a las que Freud les atribuía ser el elemento dinamizador del arte (91); del mismo modo, tras el concepto de ficción como un ajuste de cuentas con la realidad, toda vez que en esta se vive una profunda insatisfacción, se identificaría la presencia nietzscheana de la venganza que tiene el artista contra un sistema y una realidad profundamente represoras (91); y cuando se precisa que existe una articulación lógica entre la plasmación de la temática y los procesos del inconsciente, el vínculo con Gilles Deleuze es evidente, pues tanto para él como para Vargas Llosa:

la verdadera temática de una obra no es por tanto el tema tratado, tema consciente y querido que se confunde con lo que las palabras designan, sino los temas inconscientes, 
los arquetipos involuntarios en los que las palabras, y también los colores y los sonidos, toman su sentido y su vida (91).

No hay duda de que la mitología de la escritura, la sistematización y plasmación de la temática son cuestiones de orden «pretextual» (92), probablemente, más acordes con la crítica genética, es cierto, pero Williams nos hace comprender que más que un demérito o signo de premodernidad, la insistencia en estos tópicos — por más de medio siglo- debe llevarnos a pensar no tanto en la escasez de novedosos fundamentos, por el contrario, estos son evidencia de que Vargas Llosa es uno de aquellos pocos novelistas cuya reflexión sobre el proceso creativo es rigurosamente sistemática: «no hay novelista latinoamericano que haya escrito con una conciencia tan desarrollada de su acto creador» (92). Y si esto confirma todavía más la filiación vargasllosiana a modelos explicativos decimonónicos, esos que están un paso antes de la inmersión en el textualismo y mucho antes de la proclama y la muerte del autor, pues entendamos que la tesis de la homologación conceptual exige realizar una relectura de la ensayística vargasllosiana no invocando acríticamente las tesis del vacío epistemológico o la autorreferencialidad; el paso más allá exige que se reconozca que estas pueden ser falseadas para enriquecer la comprensión de una producción ensayística que desde hace ¡cuarenta años! sigue leyéndose del mismo modo. En tal sentido, la tesis de la homologación conceptual y sus complementos comparativos tienen su fundamento en el ocaso (o el prolongado eclipse) de uno de los metarrelatos más excitantes y con mayor raigambre en los estudios literarios (y que de hecho es el sustento 
de la tesis de Rama, Moraña y una extensa nómina de críticos), nos referimos al metarrelato de la cientificidad de las ciencias del lenguaje (léase: de la teoría literaria):

Desde la publicación de su ensayo crítico García Márquez: historia de un deicidio, la crítica académica ha visto la llegada (y la salida), para bien o para mal, de la «revolución teórica» que nos había traído el análisis estructuralista, semiótico, neomarxista y postestructuralista. Para comienzos del nuevo siglo, varios de esos discursos [...] parecen estar en su ocaso. No obstante, sería más apropiado hablar, hoy en día, de la «intertextualidad» en la obra de Vargas Llosa, en vez de sus «demonios». Y en cuanto a la famosa «muerte» del autor anunciada por Barthes, es notable que las cosas han salido básicamente al revés de lo que se suponía: la biografía literaria es uno de los géneros más de moda hoy en día (y el recién fallecido Barthes, tan de moda en los años setenta y ochenta, es una figura relativamente olvidada en los años noventa). Fue un gran atrevimiento por parte de Vargas Llosa, en 1971, basar un libro en la experiencia personal de un autor precisamente durante la época del frenesí «textual» $[. .$.$] los$ autores nunca se murieron del todo en América Latina, a pesar de los esfuerzos por parte de los teóricos franceses por «matarlos», digamos, metafóricamente (286, nuestras cursivas).

La propuesta que se desprende de este extenso fragmento es bastante clara: si la escritura crítica vargasllosiana fue recusada - hace cuarenta años- por carecer de fundamentos teóricos modernos y por ser demasiado biografista, ¿cómo la leemos en el contexto actual donde los fundamentos teóricos han sido profunda y radicalmente cuestionados?, ¿cómo leer (analizar, interpretar, valorar) aquellos pasajes biográficos donde el ensayista abordó somera o extensamente la 
vida de distintos autores, cómo si es que la educación de la mirada crítica sobre sus ensayos hacía que los descalifiquemos precisamente por ser de esa estirpe de escrituras que repasan la vida o que recorren superficialmente por sobre el texto, sin reparar en sus estructuras profundas?

Los pasajes argumentativos donde Williams ofrece la plasmación de los efectos de estas interrogantes son sintéticos y se reducen a operar el paralelismo o identificar los aires de familia conceptuales que enmarcan las ideas vargallosianas dentro del campo semántico de las ideas de Freud y Deleuze. Por ello es que decíamos que la suya es una postura que define la tesis de la homologación conceptual. Es cierto que la intención explícita de Williams no es brindar un análisis de la ensayística vargasllosiana, si no lo explicamos antes, pues precisemos -ahora- que su estudio tiene como centro de atención la producción narrativa desde Los jefes (1959) hasta La fiesta del chivo (2000), y para discurrir por estas propuestas narrativas estructura su riguroso libro replicando el modelo analítico vargasllosiano empleado en el extenso estudio sobre Gabriel García Márquez, así como el crítico-novelista, Williams denomina «La realidad real» a esa suerte de relato sobre los orígenes y el proceso de formación y maduración de la conciencia intelectual y escritural; y llama «La realidad ficticia» al apartado donde, efectivamente, se estudian los diversos elementos que confluyen en la producción narrativa vargasllosiana; estos datos vienen a cuento para comprender que para Williams son completamente válidas (actualmente) algunas de las categorías vargasllosianas acuñadas en 
la década de los años setenta, pues así como sirven para el estudio sistemático de la obra de Vargas Llosa, también pueden ser útiles para el análisis riguroso de la producción literaria de autores diversos, es más, el texto de Williams - sin pretenderlo- actualiza un modelo de aproximación al autor y de análisis de su obra empleando el utillaje conceptual no solo de la historiografía literaria, la hermenéutica y la biografía, sino también del campo de la historia social e intelectual latinoamericana.

Resulta radicalmente expresivo el pasaje final que citamos líneas arriba toda vez que en aquel se traza de un plumazo la idea del fracaso de la racionalidad instrumental que exigía construir algoritmos narrativos o gramáticas de la creación estructurales tanto a los teóricos como a los críticos. Es más significativo aún, pues el espacio donde se está inscribiendo este lapidario resumen de su eclipse y final, es un modelo de texto crítico construido con varios de los elementos del modelo vargasllosiano; efectivamente, se está señalando el fracaso de la orientación crítica dentro de las estructuras discursivas de un modelo de desarrollo argumentativo que, como lo hemos explicado, se ha cuestionado, desde hace cuarenta años, por no estar estructurado respetando las cláusulas del protocolo de composición crítico (metalenguaje, objetividad, soporte teórico). Williams cierra su texto con dos expresivos gestos: el que señala el ocaso del metarrelato de la modernidad y sus implicancias científicas en el campo de la literatura; y la puesta en funcionamiento del modelo vargasllosiano de crítica para describir y explicar la producción narrativa de otros autores. La pregunta queda 
planteada. ¿Por dónde continuar? ¿Qué derrotero epistemológico seguir? ¿Por dónde recomenzar la reconstrucción del lenguaje de la crítica para interactuar con la producción ensayística vargasllosiana?

\section{Coda}

La presentación de las tres tesis, con sus respectivas actualizaciones, plantea la pregunta respecto a ¿cómo entender contemporáneamente los ensayos vargasllosianos? ¿Seguir insistiendo en la tesis del vacío epistemológico, la autorreferencialidad o la homologación conceptual? Si continuamos por el derrotero trazado por las dos primeras tesis, probablemente, reescribiríamos acríticamente la historia conflictiva de los actores conceptuales, el drama de la negación cognoscitiva y el conocido final del vacío epistémico o la condena conceptual de reflejarse en el espejo; es evidente que no pretendemos repetir el mismo argumento. Proponemos, más bien, ampliar y enriquecer la tercera tesis, aquella de la homologación conceptual. Si lo recordamos, se trata de una posición argumental que redefine el modo de interacción y comunicación con la escritura ensayística vargasllosiana. Para ello busca desautomatizar el sistema perceptivo y analítico de la crítica, pues considera que esta operación mecánica ha guiado equivocada y monológicamente la comprensión de la ensayística vargasllosiana. Los ajustes que invoca se hacen en nombre de la transformación actual del campo de la teoría y la crítica. Pero si no se reescriben las anteriores tesis, entonces se comparará los argumentos vargasllosianos, jcomo se ha hecho antes!, ¿con las ideas de Sartre, Camus, Flaubert 
y algunos otros? Cuando proponemos ampliar la tesis de la homologación conceptual buscamos abrir nuevos derroteros comparativos toda vez que resulta importante interrogar si las ideas que Vargas Llosa ha propuesto por más de medio siglo tienen algún punto de contacto con los postulados actuales de la teoría literaria o la reflexión sobre la literatura, si bien hace más de dos décadas Castro-Klarén propuso ir despacio en la comparación de las ideas de novela que tienen tanto Vargas Llosa como Bajtín, después de este inaugural gesto comparativo, al que se suma el realizado por Castañeda cuando encuentra que la insistencia en mostrar el proceso creativo al lector tiene cierta correspondencia con la estética de la recepción y las teorías de la lectura, y la propuesta de Williams cuando invoca a Deleuze para comprender las fuerzas productivas del inconsciente, salvo estas aproximaciones que escapan de los lugares comunes de la crítica vargasllosiana, no existen otros esfuerzos comparativos que calibren correspondencias para entender de otro modo la ensayística literaria vargasllosiana. Por tanto, proponemos leer la ensayística vargasllosiana sobre la literatura en sintonía, familiaridad y parecido con los planteamientos que la teoría de la literatura realiza en la actualidad; de este modo, se propone romper o contribuir con falsear dos de las tesis más reproducidas desde las tres últimas décadas del siglo pasado: la tesis del vacío epistemológico y la autorreferencialidad. 


\section{Bibliografía}

BARTHES, Roland. «La muerte del autor», en El susurro del lenguaje. Barcelona, Paidós, 1987 [1968], págs. 65-71.

CASTAÑEDA, Belén S. «Mario Vargas Llosa: El novelista como crítico», en Hispanic Review. Vol. 58, 1990, pág. 3.

CASTRO-KLARÉN, Sara. Mario Vargas Llosa: análisis introductorio. Lima, Latinoamericana, 1988.

COQUET, Jean-Claude. En busca del sentido. El lenguaje en cuestión. Traducción de Desiderio Blanco. Lima, Universidad de Lima, 2011.

CORNEJO POLAR, Antonio. «Para una teoría de la literatura hispanoamericana: a veinte años de un debate decisivo», en Revista de Crítica Literaria Latinoamericana. $\mathrm{N}^{\circ}$ 50, 1999, págs. 9-12.

EICHENBAUM, Boris. "La teoría del "método formal"». TODOROV, Tzvetan (comp.). Teoría de la literatura de los formalistas rusos. México, Siglo XXI, 2008, págs. 31-76.

FRANCO, Jean. Decadencia y caída de la ciudad letrada. La literatura latinoamericana durante la Guerra Fría. Barcelona, Debate, 2003.

FRANCO, Sergio R. «Mario Vargas Llosa. El lenguaje de la pasión», en Revista de Crítica Literaria Latinoamericana. $\mathrm{N}^{\circ}$ 56, 2002, págs. 273-276.

GRANÉS, Carlos. «El quiebre histórico», en La revancha de la imaginación. Antropología de los procesos de creación: Mario Vargas LLosa y José Alejandro Restrepo. Madrid: Consejo Superior de Investigaciones Científicas, 2008, págs. 55-57. 
KING, John. «The Essays», en KRISTAL, Efraín y John KING (eds.). The Cambridge to Mario Vargas Llosa. Cambridge/New York/Cambridge, Cambridge University Press, 2015, págs. 148-173.

KOBYLECKA-PIWONSKA, Ewa. «Teoría crítica de Mario Vargas Llosa: entre autorretrato y discurso autoritario», en Kwartalnik Neofilologiczny. LV, 2, 2007, págs. 141-156.

KRISTAL, Efraín. "La política y la crítica literaria. El caso de Vargas Llosa», en Perspectivas. Vol. 4. N ${ }^{\circ}$ 2, 2001, págs. 339-351.

MIGNOLO, Walter. «¿Teorías literarias o teorías de la literatura? ¿Qué son y para qué sirven?», en REYES, Graciela (ed.). Teorías literarias en la actualidad. Madrid, El Arquero, 1989, págs. 41-78.

MORAÑA, Mabel. Arguedas/Vargas Llosa: dilemas y ensamblajes. Madrid, Iberoamericana, 2013.

OVIEDO, José Miguel. Mario Vargas Llosa: la invención de una realidad. Barcelona, Seix Barral, 1982 [1970].

PAZ, Octavio. «Sobre la crítica», en Corriente alterna. México, Siglo XXI, 1967, págs. 39-44.

POZUELO YVANCOS, José María. Teoría del lenguaje literario. Madrid, Cátedra, 1994.

PULIDO TIRADO, Genara. Constelaciones de teorías. El giro culturalista en los estudios literarios latinoamericanos. Vigo, Academia de Hispanismo, 2009.

RAMA, Ángel. «La generación hispanoamericana del medio siglo. Una generación creadora», en Marcha. 1217, 1964, págs. 2-10. 
. «Carta de Ángel Rama a Zona Franca», en Zona Franca. 16, 1972, págs. 10-15.

. «Demonio vade retro», en García Márquez y la problemática de la novela. Buenos Aires, Corregidor, 1973, págs. 7-11. . «La guerra del fin del mundo. Una obra maestra del fanatismo artístico", en La crítica de la cultura en América Latina. Selección y prólogos de Saúl Sosnowski y Tomás Eloy Martínez. Cronología y bibliografía de la Fundación Internacional Ángel Rama. Caracas, Biblioteca Ayacucho, 1985, págs. 335-363.

RAMA, Ángel y Mario VARGAS LLOSA. García Márquez y la problemática de la novela. Buenos Aires, Corregidor, 1973.

RANCIÈRE, Jacques. La palabra muda. Ensayo sobre las contradicciones de la literatura. Traducción de Cecilia González. Buenos Aires, Eterna Cadencia, 2009.

RUFFINELLI, Jorge. «Ángel Rama, Marcha, y la crítica literaria latinoamericana en los 60s», en Casa de las Américas. 192, 1993, págs. 30-37.

SÁNCHEZ LÓPEZ, Pablo. La emancipación engañosa. Una crónica transatlántica del boom (1963-1972). Alicante, Universidad de Alicante, 2009.

VARGAS LLOSA, Mario. El lenguaje de la pasión. Lima, Peisa, 2001.

WILLIAMS, Raymond L. Vargas Llosa: otra historia de un deicidio. México, Taurus/Universidad Autónoma de México, 2001. 